\title{
Correlation between Concentrations of Some Heavy Metal in Poultry Feed and Waste
}

\author{
Richard Alexis Ukpe* and Augustine A Chokor \\ Department of Chemistry, Federal University, Nigeria
}

Submission: March 16, 2018; Published: April 26, 2018

*Corresponding author: Richard Alexis Ukpe, Department of Chemistry, Federal University, Otuoke, Bayelsa State, Nigeria, Email: ukperichard24@gmail.com

\begin{abstract}
This study was designed to investigate the possibility of soil environmental contamination by poultry excreta (i.e. poultry waste) through acquisition of heavy metals ions during feeding. Common poultry feeds sold within the study area were used to feed some selected poultry birds and the excreted product were analysed after three weeks interval. The analyzed feeds were found to contain some heavy metals which eventually enriched the waste with similar heavy metals. Concentrations of heavy metal ions in the analysed poultry waste were $\mathrm{Ni}(1.89 \mathrm{~g} / \mathrm{kg})$, Co $(0.43 \mathrm{~g} / \mathrm{kg}), \mathrm{Pb}(1.17 \mathrm{~g} / \mathrm{kg}), \operatorname{Cr}(0.846 \mathrm{~g} / \mathrm{kg})$ and Cd $(0.53 \mathrm{~g} / \mathrm{kg})$ respectively. Concentrations in the feeds were Ni $(1.71 \mathrm{~g} / \mathrm{kg}), \mathrm{Co}(0.39 \mathrm{~g} / \mathrm{kg})$, $\mathrm{Pb}(1.17 \mathrm{~g} / \mathrm{kg}), \mathrm{Cr}(0.529 \mathrm{~g} / \mathrm{kg})$ and $\mathrm{Cd}(0.031 \mathrm{~g} / \mathrm{kg})$ respectively. There was strong correlation between the analyzed heavy metals in the feed and in their excreted waste, which indicated that poultry feed has the potential to contaminant several components of the environment.
\end{abstract}

Keywords: Heavy metal contamination; Poultry feed; Excreted product; Correlation

\section{Introduction}

Most animal feeds including poultry feed are known sources if heavy metal pollution. Heavy metal contamination of poultry birds can arise from feed or water. Most often, heavy metal can be transfer from the soil to plant, animal and consequently man through progressive food chain and bioaccumulation. Most often, poultry feed is produced from plant materials indicating that if the plant is contaminated, the feed will also be contaminated. Raw materials for some poultry feeds include rice bran, rice polish, solvent extracted rice and wheat bran and molasses. Others include minerals and vitamins including calcium, phosphorus, trace minerals (such as $\mathrm{Fe}, \mathrm{Zn}, \mathrm{Mn}, \mathrm{Cu}, \mathrm{CO}$ and me) and vitamins $\mathrm{A}_{3} \mathrm{D}_{3}, \mathrm{E}, \mathrm{K}$ and $\mathrm{B}$ complex.

Jongbloed \& Lenis [1] stated that swine grown for animal feed production is generating serious environmental concerns because the structure of swine production has changed dramatically in the last four decades. Also Raw materials for swine feeds are often grown in regions other than where swine production takes place. Swine manure is mostly spread in the neighborhood of the facilities, which may lead to soil accumulation of heavy metals, among other minerals. Studies have shown that the use of manure to fertilize the soil has resulted in higher concentrations of heavy metal in such soil compared to the control sites [2-4].

Studies on heavy metal concentrations in some domestic animal, their feed and manure have been reported by some authors. Wang et al. [5], found that mean concentrations of Zn, $\mathrm{Cu}, \mathrm{Hg}, \mathrm{As}, \mathrm{Cd}$ and $\mathrm{Cr}$ in some animal feeds were 15.90, 2041.80, 8.40-1726, 39.50-11379 and $1.0-1602 \mathrm{mg} / \mathrm{kg}$ respectively. Astronomical increases in concentration of $\mathrm{Cu}, \mathrm{Zn}, \mathrm{As}, \mathrm{Cr}$ and $\mathrm{Cd}$ contents were observed in pigs manure, diary manure and poultry manure. Zhang et al. [6] studied heavy metal content of poultry waste collected from several farms within Northeast China and found that mean concentrations of $\mathrm{Cu}$, As and $\mathrm{Cd}$ ions ranged from 2.3 to $1.14 \mathrm{mg} / \mathrm{kg}, 0.02$ to $13 \mathrm{mg} / \mathrm{kg}$ and from non detectable to $3.1 .65 \mathrm{mg} / \mathrm{kg}$ in pig feed. In poultry feed, the concentrations ranges were 2.88 to $98.08 \mathrm{mg} / \mathrm{kg}, 0.02$ to $6.42 \mathrm{mg} / \mathrm{kg}$ and non detectable to $8.00 \mathrm{mg} / \mathrm{kg}$ of $\mathrm{Cu}$, as and $\mathrm{Cd}$ respectively. However, the corresponding mean concentration in pig manure were $65.60 \mathrm{mg} / \mathrm{kg}, 3.3 \mathrm{mg} / \mathrm{kg}$ and $1.6 \mathrm{mg} /$ $\mathrm{kg}$ while those in poultry manure were $31.1 \mathrm{mg} / \mathrm{kg}, 0.5 \mathrm{mg} /$ $\mathrm{kg}$ and $0.5 \mathrm{mg} / \mathrm{kg}$ of $\mathrm{Cu}$, As and Cd respectively. Their results indicate that some animals can be enriched with heavy metals through their feed. Islam et al. [7] found that the various sources of raw materials used for poultry feed production are likely associated with anthropogenic heavy metal pollution. They also reported mean concentrations of heavy metals in some poultry feeds sold in Bangladesh to include, 0.1852 - 0.0232 ppm for cadmium, $20.6498-0.6019$ ppm for lead, $0.7640-0.0069 \mathrm{ppm}$ for arsenic, $0.0579-0.0116$ ppm for mercury, $0.0347-0.0069$ ppm for selenium, 5.7875 - 0.0926 ppm for chromium, 302.2001 - 0.0695 ppm for manganese, 5.1625 - 0.0125 ppm for nickel, 
$37.5725-0.0463$ ppm for copper, and $422.3023-0.0232 \mathrm{ppm}$ for zinc. Alexieva et al. [8] also found elevated concentration of lead and cadmium in some poultry and pig feeds and their manure. These heavy metals were also found to be retained by the animal in some of their organism, indicating that significant concentration of heavy metal in feed can influence man, who is the final consumer in the food chain.

Heavy metal pollution from feed or manure depends on several factors. For example, Irshad et al. [9] carried out experiments to compare changes in $\mathrm{Cd}, \mathrm{Hg}, \mathrm{Ni}$ and $\mathrm{Pb}$ concentrations fractions in cow, goat, sheep, chicken, and ostrich livestock manure. The metals were stepwise fractionated into exchangeable, adsorbed, organically bound, carbonate-precipitated, and residual forms by extracting with $0.5 \mathrm{M} \mathrm{KNO}_{3}$, de-ionized water, $0.5 \mathrm{M} \mathrm{NaOH}$, $0.05 \mathrm{M} \mathrm{Na}_{2}$ EDTA, and $4 \mathrm{M} \mathrm{HNO}_{3}$ respectively. Extractability of HM was found to be highly dependent upon the type of manure as well as extracting agent. They found that manures differed for the release of heavy metals in the order of chicken $>$ ostrich $>$ sheep $>$ cow $>$ goat while the order for the released heavy metals was $\mathrm{Ni}>\mathrm{Pb}>\mathrm{Cd}>\mathrm{Hg}$. Voorburg [10] found that if the application rates of manure do not exceed the crop uptake of nutrient, pollution by animal production is mainly caused by nitrogenous substances but pollution from manure application outside the growing season affects groundwater and surface water due to leaching and surface runoff. The complexing properties of nitrate salts with heavy metal within the environment will also endangered the aquatic environment with heavy metal pollution.

The above review revels that poultry waste can constitute a major contaminant to the land, water and even air components of the environment through leaching, bioaccumulation, food chain (i.e. through consumption of affected plant or animal). However, even if numerous studied that have been reported elsewhere by several researchers, apart from the one reported by Okoye et al. [11], literature is scanty on correlation between heavy metal content of feed, manure and animal products in Nigeria [12]. Therefore, the present study is aimed at investigating the relationship between heavy metal concentration of feed and manure in poultry birds within Bayelsa environment.

\section{Materials and Methods}

Five different poultry feeds were purchased within Yenegoua metropolis in Bayelsa state of Nigeria. Five farms using the purchased products to feed their birds were identified and the excreted products from the experimental birds were collected. Heavy metal determination was carried out using atomic absorption spectrophotometer.

\section{Results and Discussions}

Concentrations of heavy nickel, cobalt, lead, chromium and cadmium ions in poultry waste and feeds are recorded in Tables 1 \& 2 respectively. From the results obtained, mean concentration of nickel ion in poultry waste and feed samples were 1.89 and $1.71 \mathrm{mg} / \mathrm{g}$. The distribution exhibited standard deviation of 0.022 and 0.02 respectively the results indicate that average concentration of nickel ion in the poultry waste exceeded the concentration in the feed suggesting that the excess concentration is due to bioaccumulation and subsequent excretion. Bioaccumulation defines a process that defines an increase in concentration of heavy metal ion with time due to continuous addition and accumulation. Mean cobalt ions concentration in the poultry waste $(0.43 \mathrm{mg} / \mathrm{g})$ was higher than mean cobalt concentration in the poultry feed $(0.39 \mathrm{mg} / \mathrm{g})$ and exhibited standard deviation of 0.013 and 0.009 respectively. This indicates that concentration of cobalt ions in poultry waste is more widely distributed than in poultry feed.

Table 1: Concentration of heavy metals ions in poultry waste.

\begin{tabular}{|c|c|c|c|}
\hline Heavy Metal & Mean & SD & \%RSD \\
\hline $\mathrm{Ni}$ & 1.89 & 0.022 & 1.18 \\
\hline $\mathrm{Co}$ & 0.43 & 0.013 & 2.96 \\
\hline $\mathrm{Pb}$ & 1.17 & 0.125 & 10.72 \\
\hline $\mathrm{Cr}$ & 0.846 & 0.56 & 6.59 \\
\hline $\mathrm{Cd}$ & 0.53 & 0.001 & 1.69 \\
\hline
\end{tabular}

Table 2: Concentration of heavy metals ions in poultry feed.

\begin{tabular}{|c|c|c|c|}
\hline Heavy Metal & Mean & SD & \%RSD \\
\hline $\mathrm{Ni}$ & 1.71 & 0.02 & 1.25 \\
\hline $\mathrm{Co}$ & 0.39 & 0.009 & 2.18 \\
\hline $\mathrm{Pb}$ & 1.17 & 0.071 & 6.06 \\
\hline $\mathrm{Cr}$ & 0.529 & 0.061 & 11.63 \\
\hline $\mathrm{Cd}$ & 0.031 & 0.005 & 16.66 \\
\hline
\end{tabular}

Average concentrations of lead ion in poultry waste and in the feed were 1.17 and $1.17 \mathrm{mg} / \mathrm{g}$ respectively. The similarity in concentration reveals that poultry birds have the potential of excreting intake lead ion from their systems. This potential can however be altered at elevated concentration because the lead ion might have been diffused into the body system. Lead is a heavy metal that has the tendency to poison the blood system. Mean concentration of chromium ion in poultry waste $(0.846$ $\mathrm{mg} / \mathrm{g}$ ) was higher than mean concentration of chromium in the poultry feed $(0.529 \mathrm{mg} / \mathrm{g})$. The distribution recorded standard deviations of 0.56 and $0.061 \mathrm{mg} / \mathrm{g}$ respectively. The higher variability in the distribution of chromium ion in the poultry waste confirms that bioaccumulation and subsequent excretion must have been responsible for the elevated concentration of lead in the waste (Table $1 \& 2$ ).

Figure 1 contains bar charts showing the levels of distribution of the study heavy metal ions in the poultry waste and feed. The Figure clearly reveals that nickel ions are the most dominant heavy metal ion in the feed and waste samples while cobalt ions are the least. Except lead ions, all the heavy metals ions exhibited variation in concentration in the feed and waste. There was no significant difference between the concentrations of heavy metals ion in the poultry waste and feed $\left(\mathrm{t}_{\mathrm{Cal}}=0.30878\right)$ at 0.05 level of significant. Figure 2 presents a plot showing 
the variation of concentrations of heavy metals ions in the feed and in the waste. Calculated value of degree of linearity $\left(\mathrm{R}^{2}=\right.$ 0.9114) indicates that the concentrations of heavy metals ions in the waste increase as the concentration in the feed increases. It is worth stating that an investigation presented in this study is bound to give one of the following three sets of possible expectation a) Higher values of heavy metals in the waste than in the feed and vice versa

b) Higher values of heavy metal in the feed than in the waste and vice versa

c) Similar concentrations of heavy metals in the feed and waste

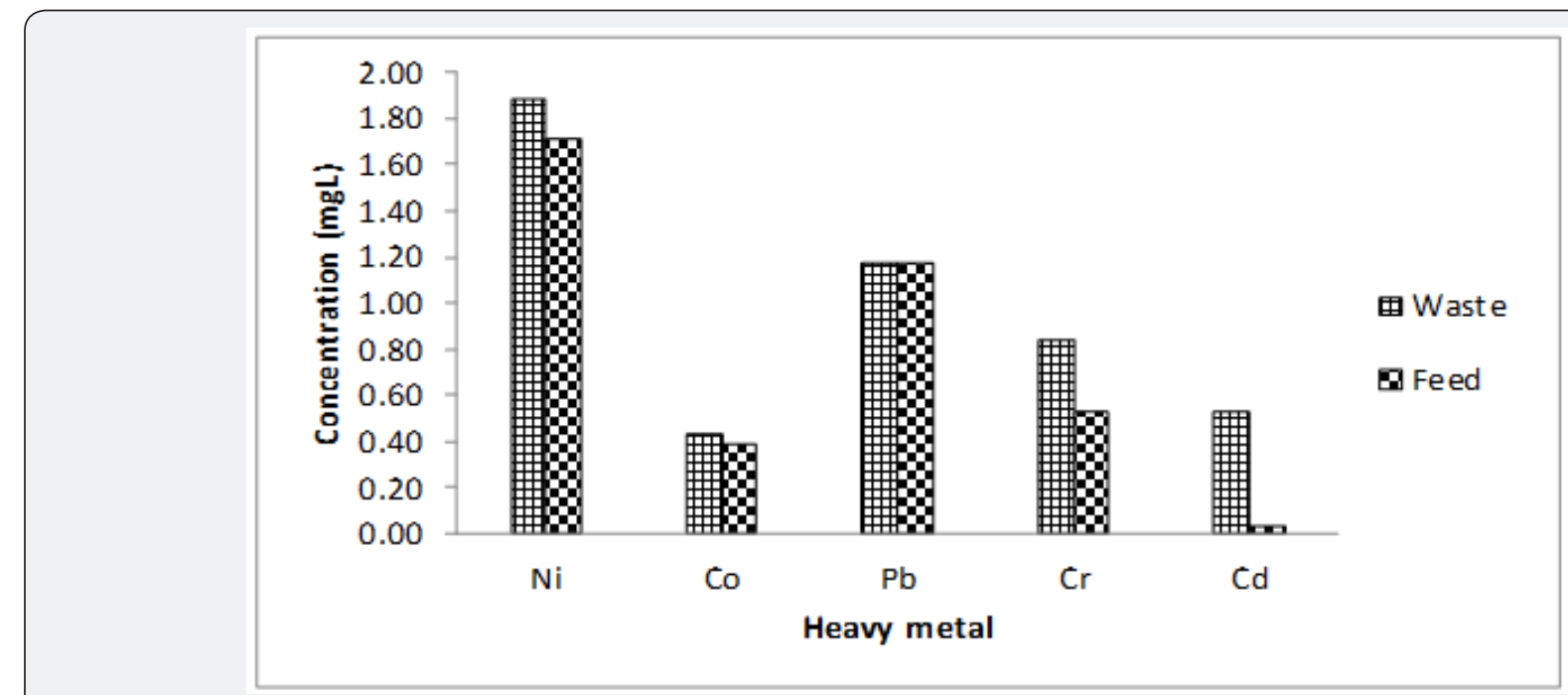

Figure 1: Levels of concentrations of heavy metal ions in poultry feed and waste.

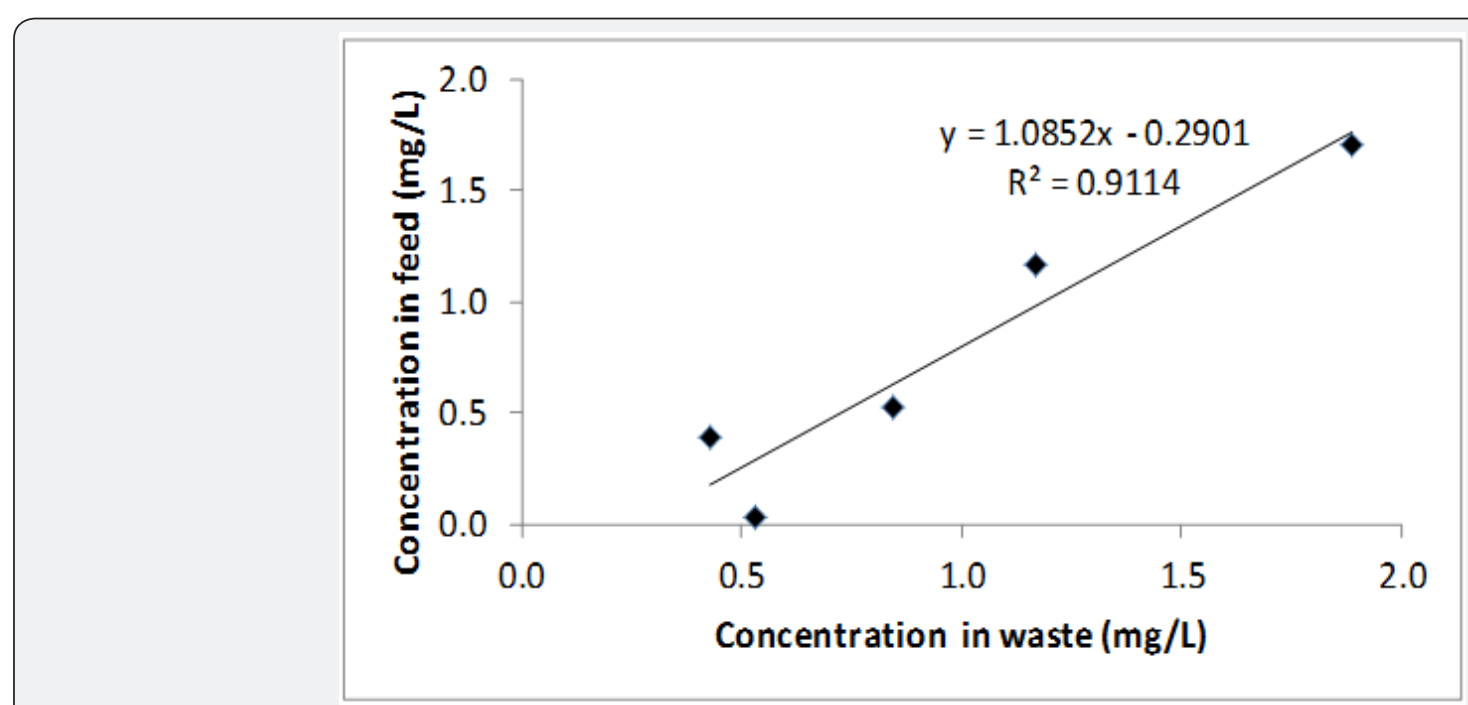

Figure 2: Variation of heavy metal ions in poultry feed and poultry waste.

The first suggests that bioaccumulation/biomagnification as well as contribution from other sources (especially water intake) is likely. The second will be liken to situations where the heavy metals is been trapped in the organs of the poultry beds indicating endangering toxicity at elevated concentration. However, the third points to cases where the heavy metal ions are completely discarded off the system through excretion. In this study, case I was observed for nickel, chromium, cadmium and cobalt ions while case iii was observed for only lead. Case ii was never observed. Therefore, factors reveals in the present study are bioaccumulation/biomagnification, complete excretion (for lead ions) and contribution from water intake. However, although assimilation into body organs has not be established from the present study, it is possible that at elevated concentrations of heavy metals ions, bioaccumulation (without complete excretion) and subsequent toxicity through the food chain can lead to heavy metal toxicity. The toxicity of these heavy metals ions have been highlighted in literature review hence there is need to control heavy metal ions in poultry feed and water (Figure $1 \& 2$ ). 


\section{Conclusion}

The present study reveals that poultry feeds have the potentials to contribute to heavy metal pollution of the soil (through application of manure), water (through leaching) and living things including plant and animals(through the food chain)

\section{Acknowledgement}

The corresponding author of this work, Dr. Richard Ukpe greatly acknowledges his supervisor, Prof. Nnabuk Okon Eddy for his contribution in the research that led to the publication of this article.

\section{References}

1. Jongbloed AW, Lenis NP (1998) Environmental concerns about animal manure. J Anim Sci 76(10): 2641-2648.

2. Guerra Rodriguez E, Alonso J, Melgar MJ, Vazquez M (2006) Evaluation of heavy metal contents in co-composts of poultry manure with barley wastes or chestnut burr/leaf litter. Chemosphere 65(10): 1801-1805.

3. Gupta G, Charles S (1999) Trace elements in soils fertilized with poultry litter. Poultry Science 78(12): 1695-1698.

4. Jaja N, Mbila M, Codling EE, Reddy SS, Reddy CK (2013) Trace metal enrichment and distribution in poultry litter-ammended soil under different tillage practice. The Open Agriculture Journal 7(12): 88-95.

5. Wang H, Dong Y, Yang Y, Toor GS, Zhang X (2013) Changes in heavy metal contents in animal feeds and manures in an intensive animal production region of China. Journal of Environmental Science 25(12): 2435-2442.

6. Zhang F, Li Y, Yang M, Li W (2012) Content of heavy metals in animal feed and manure from farms of different scale in Northern China. International Environmental Research and Public Health 9(8): 26582668.

7. Islam MS, Kazi MAI, Hossain MM, Ahsan MA, Hossain AM (2007) Propagation of heavy metals in poultry feed production in Bangladesh. Bangladesh Journal of Scientific and Industrial Research 42(4): 465474 .

8. Alexieva D, Chobanova S, Iichev A (2007) Study on the level of heavy metal contamination in feed materials and compound feed for pigs and poultry in Bulgaria. Trakia Journal of Sciences 5(2): 61-66.

9. Irshad M, Malik AH, Shaukat S, Mushtaq S, Ashrate M (2013) Characterization of heavy metals in livestock manures. Pollution Journal of Environmental Studies 22(4): 1257-1262.

10. Voorburg JH (1991) Pollution by animal production in The Netherlands: solutions. Rev Sci Tech 10(3): 655-668.

11. Okoye COB, Ibeto CN, Ihedioha JN (2011) Assesement of heavy metals in chicken feeds sold in South Easter Nigeria. Advances in Applied Science Research 2(3): 63-68.

12. Li Y, McCrory DF, Powell JM, Saam H, Jackson Smith D (2005) A survey of selected heavy metal concentrations in Wisconsin dairy feeds. J Dairy Sci 88(8): 2911-2922.

\section{Your next submission with Juniper Publishers will reach you the below assets}

- Quality Editorial service

- Swift Peer Review

- Reprints availability

- E-prints Service

- Manuscript Podcast for convenient understanding

- Global attainment for your research

- Manuscript accessibility in different formats

( Pdf, E-pub, Full Text, Audio)

- Unceasing customer service

Track the below URL for one-step submission https://juniperpublishers.com/online-submission.php 